\title{
LANGUAGE LEARNING GAMES DEVELOPMENT BASED ON CURRICULUM 2013
}

\author{
Ni Wayan Surya Mahayanti \\ Universitas Pendidikan Ganesha, Indonesia \\ Email:surya.mahayanti@undiksha.ac.id
}

\author{
G.A.P. Suprianti \\ Universitas Pendidikan Ganesha, Indonesia \\ Email:gap.suprianti@undiksha.ac.id \\ I Putu Indra Kusuma \\ Universitas Pendidikan Ganesha, Indonesia \\ Email: indra.kusuma@undiksha.ac.id
}

\begin{abstract}
This research aimed at developing character based language learning games in teaching English which can be used by teacher of junior high school grade VII as an alternative activities in the classroom. This research is R\&D which used the design from Sugiyono (2011). The data in this study were collected through in depth interview, observation, and questionnaire distribution for both teacher and students. Then the data gained were analyzed qualitatively as the basis to develop the games and manual. As the result, 3 character based language learning games are developed; they are Word Bricks, Race Words dan Snake and Signs games. Validation from experts has been conducted and the scores given indicate that the product designed can be categorized as good games and excellent manual. It is also found that the product developed is categorized as good games and manual based on teacher's score. After the implementation, it is shown that the students are motivated in learning English by using games. Besides, it is also found that students' characters are starting to emerge in students who played the games.
\end{abstract}

Keywords: Language learning game, manual, character education

\section{Intruduction}

In Indonesia, English is taught as a foreign language where the teaching is only formal in the classroom. This situation makes the opportunity to learn English limited, especially for children. This tends to cause students' interest in learning English quite low. To overcome this, the teacher has to be observant and creative in choosing the approaches, methods, strategies, and techniques used in teaching. It is of course needed to maximize the motivation of students in following the learning of English in the classroom. One technique that can be used is using games (Richards \& Rodgers, 2001).

Games, as one of the techniques in teaching English, has a crucial role in improving students' learning motivation. Students often feel happy when learning English in the form of a game. Diana (2010) mentioned that with games, students become more interested in learning the material. Furthermore, Diana (2010) added that by using games in learning, teachers can create an atmosphere that would raise students' awareness to learn the language. Students will learn better if they experienced progress in learning, and games provided opportunities for students to practice and eliminate their fears (Richards \& Rodgers, 2001). This opinion is in line with Ersoz (2000) who believed that games are very motivating in language learning because games are very entertaining and interesting. Games can also be used as an exercise of all four language skills and in any kind of communication (Ersoz, 2000). Wright, Betteridge, \&Buckby (2005) mentioned that games are a context member of meaningful communication gained as students tried to understand how to play and when they discussed games.

Koksal, et al (2014) suggested games, especially language games, can be an excellent alternative to teaching grammar in a foreign language class. Teaching foreign languages with games can be an alternative strategy in a foreign language class where games give opportunities for students to enjoy the experience of learning the language and mastering knowledge and skills in a fun way. In addition, with the opportunity for students to improve their English mastery, such as preparing the learning situation, can help them develop the ability to work together and socialize and confidence using English. Games also facilitate students who have different types of learning to maximize their potential. Based on Bradley, et al (2010), games have several characteristics that benefitted language learning: (1) Involving all students in learning, (2) Giving students opportunities to collaborate and cooperate, and (3) Providing a fun learning experience. 
The implementation of games in the classroom have had a very positive impact on student learning outcomes. From several studies, it is mentioned that games are able to stimulate students to be more active in using the language they are learning. Masri \& Najar (2014) suggested that word play at the initial level is very effective in teaching English vocabulary. Furthermore, Koksal (2014) found that learning grammar with divergence is very effective and able to increase student motivation, change student attitudes toward English in a positive direction, increase self-confidence, and become the beginning for better grammar learning. Aslanabadi \& Rosouli (2013) mentioned that games are able to make students understand the vocabulary and remember it because of the cheerful situation in their learning. In line with Aslanabadi \& Rosouli, Azar (2012) also stated that games are very effective for students in improving their vocabulary skills. From the various researches, it is obvious that games play a role in improving students' English proficiency.

Games should not only be fun, but they can also teach students both in terms of knowledge, skills, and character. This is in line with the current government program in education that is related to character education. Set forth in the National Character Education Action Plan, Kemdiknas (2010), character education is a value education, moral education, moral education, character education that aim to develop the ability of all citizens to give good decisions, examples, maintaining what is good, and implementing kindness in everyday life. Based on what have been disclosed above, character education is not just teaching what is right and what is wrong. Moreover, character education is an effort to inculcate good habituation (habituation) so that learners are able to behave and act on the values that have become a personality. In other words, a good character education has to involve good knowledge (moral knowing), good feelings or loving good (moral feeling) and good behavior (moral action) so that the formation of a unity of behavior and attitude of life of learners will be made.

Furthermore, a good game is a game that is able to develop the three aspects of student learning, i.e. cognitive, psychomotor, and affective. In its implementation, curriculum 2013 emphasizes the development of students' affective aspects. Curriculum 2013 focus on the formation of the competence and character of learners, in the form of knowledge guides, skills, and attitudes that can be demonstrated by learners as a form of understanding of concepts learned conceptually (Mulyasa 2013).

Referring to the implementation of curriculum 2013, English is required to be taught in junior high school. This means that the seventh graders in junior high schools receive the foundations of the English language if their primary school did not teach English as their local content. This certainly brings an influence on the ability of students to catch the mastery of English as a foreign language. They do not have a strong foundation and will only be given the foundation when stepping on junior high school.

Based on preliminary observations conducted at SMP Negeri 4 Singaraja, the seventh-grade students still had difficulties in understanding the material when teachers taught them by using English. Most students seemed to be inactive in responding to teacher speech and were less motivated to understand what the teacher was saying. They looked less enthusiastic in learning activities. Based on the results of interviews with the teachers, it was known that the teacher had not maximized the utilization of games in the learning activities. That was because of the limited time and the lack of game references known by the teacher. Additionally, on very rare occasions, teachers applied games in classroom learning activities, and the results did spur students a bit more actively. This showed that if the teacher was able to manage the learning carefully and inserted a varied game according to the topic of discussion, then the students' activity could be improved.

Considering the explanation and phenomenon above, this study aimed to develop character based language learning games that could be used by teachers of English in junior high school grade VII as an alternative activity in the classroom. The games were developed based on topics in the curriculum of 2013 where each topic were developed some games that could be selected by the teacher.

\section{Method}

This research was a research and development with a research design that followed the model of Sugiyono (2011) which consisted of 10 stages in developing a product. The tenth steps were: (1) Identifying Potentials and Problems, (2) Collecting Data, (3) Designing Products, (4) Validating Designs, (5) Revising Draft, (6) Implementing Try-out Products, (7) Revising Products, (8) Implementing Product Usability Tests, (9) Revising Products, and (10) Doing Mass Production. However, due to the limited time of research, the product produced in this research was only at the prototype stage.

The subjects of this study were 7th-grade junior high school students and English teachers who taught at SMP Negeri 4 Singaraja. The school was chosen because it had been using the curriculum 2013. While the object of this study was language learning games based on character education in English language teaching in junior high schools grade VII.

Generally, data collection in this research used 5 data collection methods that were observation, interview, giving checklist, giving test, and literature study while the instruments used were observation sheet, interview guide, checklist, test, and note. 
In this study, the data collected were analyzed descriptively. The data obtained in the identification stage of potential and problems were explained qualitatively. It was then proceed with the data collection stage in which the data collected related to the development of language learning games based on character education in the teaching of English in junior high schools grade VII at this stage was analyzed qualitatively. At the stage of validating its own design, content validity data obtained from experts were analyzed using the Gregory formula. While the data related to the validity of the construct were analyzed qualitatively. Then, the data related to the product trial were analyzed qualitatively. The data that were analyzed qualitatively were the data obtained by using the method of interview and observation.

\section{Results and Discussion}

\section{Results}

Based on the results of needs analysis, either it was the result of observation, interview, and student questionnaire; it could be found that the students of grade VII at SMP Negeri 4 Singaraja had the potential in learning English because all students loved English learning. Unfortunately, learning strategies in the classroom often made the majority of students' bored and unmotivated learning English. In addition, the use of limited media was also a problem in learning English in the school. In connection with these findings, it was necessary to develop games as one of the alternative strategies that would assist the teacher in creating a pleasant English learning atmosphere.

The next stage of this research was developing the product of Language Learning Games in manual form. At the development stage, the first thing to do was syllabus analysis. The syllabus analysis was conducted to determine the topics to be developed into games based on the teacher's needs. The syllabus that was analyzed was the semester syllabus in the academic year 2015/2016. Based on the results of the analysis of syllabus it was gotten that of the 4 basic competencies that existed, only 3 were selected to be developed into games. These competencies were namely competencies $4.8,4.9$, and 4.11 . The last competency on 'descriptive text' was not selected because according to the teacher the students should be given a text which was then followed by an explanation of difficult words or sentences that they did not understand. In addition, the characters that should be included in each developed game were taken directly from the syllabus because, in the syllabus of K13, the characters already existed and had to be built during the learning process.

After analyzing the syllabus, the next was continued by developing the blue print game. The blue print was designed with consideration of the students' potential and problems as well as the previous syllabus analysis. Furthermore, based on the blue print, there were three types of games developed, namely Word Bricks, Race Words, and Snake and Signs game. The design of games was made using Microsoft Word 2016, Adobe Photoshop Cs6, and also Corel Draw.

The first character-based educational game developed was word bricks. The game was developed in line with the basic competence of 4.8 (constructing oral and written text to express the nature of people, animals, and things). The game aimed to get students to construct sentences using the given words, either to be, adjectives, nouns, verbs, and punctuations. Here was a draft of the word bricks.

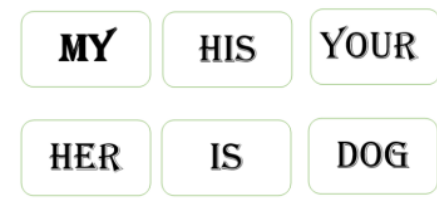

Figure 1. Word Bricks Game Design

This game was adapted from an English book entitled Activate: Games for Learning American English (2013). In the book, it was explained that Word Bricks could be used for interactive practice and teaching grammar. In addition, this game could also be used in teaching beginners in any class because the focus of games helped students understand language structures such as differences in tenses, etc.

The characters that were inserted in this game namely, discipline, honesty, fair competition, and caring. Discipline could be seen when students played by following predefined rules and did not interfere with other groups in games. Honesty could be seen from the students' obedience to the rules; they were not cheating during the games. The competition would, of course, be seen between one group to others by competing fairly and not disadvantaging other groups. Students' awareness would also be built as they would support each other's group members to be able to finish sentences in games.

The next was games Race Words Game. This game was developed in accordance with the basic competence of 4.9 (constructing oral and written text to express behavior/action of people, animals, and things). 
It was still the same as the previous game, the concept of this game was adapted from the book Activate: Games for Learning American English (2013) which design could be seen in the following picture.

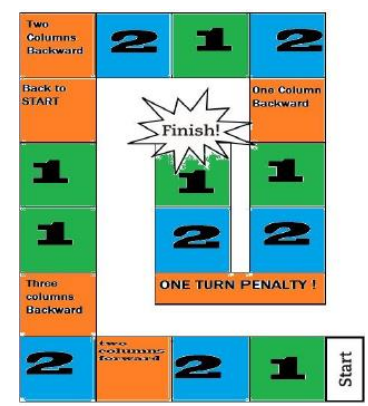

Figure 2. Race Words Game Design

The design was then modified due to some constraints encountered when it was attempted to use. The limited box caused the duration of games very short and the lack of challenge for the students' users. For that, the games design was improved to be like the picture below.

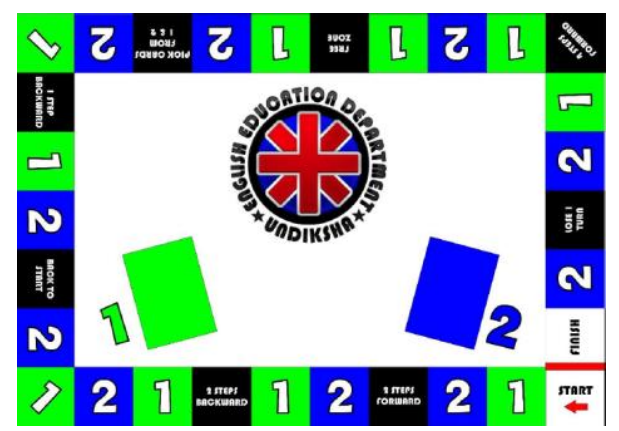

Figure 3 Race Words Game Design

The game aimed to make students recall vocabulary through games. Students were challenged to find names, function, and places on this game. These materials were provided in the form of opportunity cards that students would take depending on the number at which they stopped.

The cards provided could be seen in the following picture.
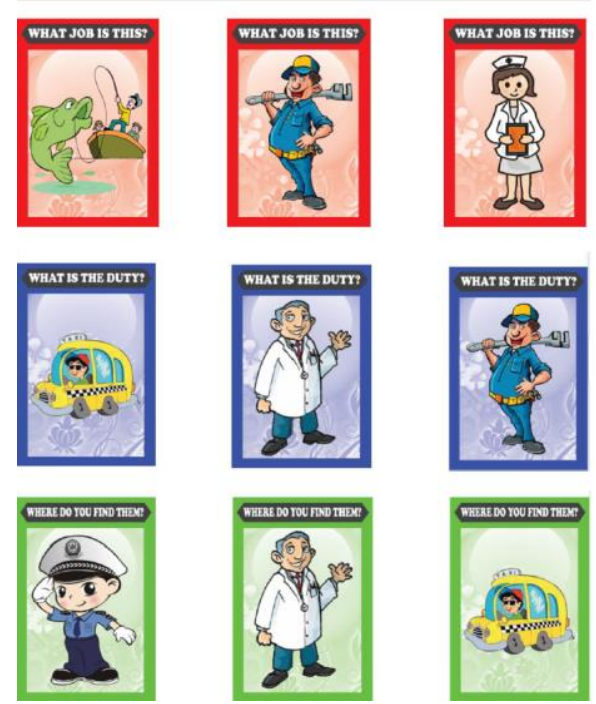

Figure 4. Cards on Race Words Game

The cards were used in this game as a question to challenge students considering the vocabulary they had learned before. There were 3 different colors on the card indicating different functions, i.e. red was asking the function of material and green was asking the place of material. 
The characters inserted in games were discipline, confidence, fair competition, and tolerance. Discipline was implanted in students when students had to follow the rules of games without cheating and disturbing other friends. Confidence was developed when students had the opportunity to answer questions without hesitation and without fear of their right or wrong answers. Competition would, of course, be seen between one group and others but in a good manner and not harming other groups. And tolerance was a character that was developed when they were waiting to turn to play, giving time to think, and when other students needed help remembering the vocabulary.

The third game was snake and signs game. This game was based on basic competence 4.11 (simple instruction constructs, signs (short notice), and warning text in oral or written). The game aimed to make students mention signs/ warnings/ short notices. Students would play a ladder snake game, and the signs/warnings / short notices they should mention based on the box where they stopped. The initial design of this game could be seen in the following figure.

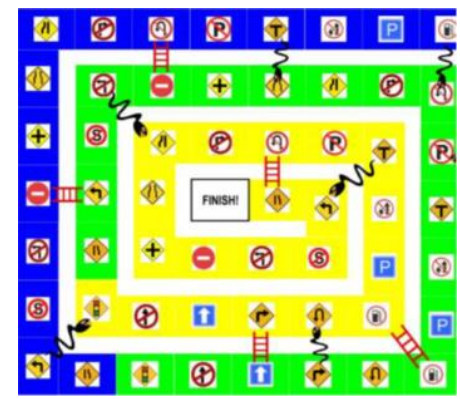

Figure 5. Snake and Signs Game Design

The board game had 3 different colors, namely blue, yellow, and green where the colors were showing different types of questions that had to be answered by students. Blue was for a sign, green was for the meaning of the signs and yellow was for spot signs. The characters inserted in games were honesty in waiting and rolling dice, fair competition to win games, justice, and responsibility so that the winner should be awarded.

To play Race Words and Snake and Ladder Games, a dice was required. A special dice was also designed by researchers as a complement and with a specific purpose. These games were designed to give students an opportunity to answer more questions and lengthen them to the end so that the dice was not from 1-6, but from 1-3. The following figure was a developed dice design.

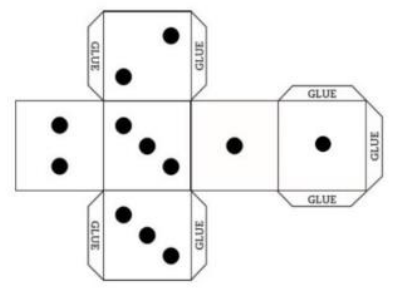

Figure 6. Special Dice Design

Furthermore, once games had been developed, then the instructions were included in a manual book. The book was certainly not designed carelessly. There was a need for designs, templates, and special content for the book.

When designing the book cover, Adobe Photoshop CS 6 applications were used. The writing was using orange copper black color with size 21.73 pt. The cover also contained pictures of 4 students who play board games in groups with cheerful facial expressions. The content or content of this book was developed using Microsoft Office Word 2016. Furthermore, the content was developed with 14 different sections, namely games, skills, characters, core competencies, basic competencies, game objectives, topic, material and preparation, teacher's role, classroom management, game's procedures, rules of games, follow-up activities, variations, and tips. Furthermore, the pictures were inserted in the manual was a scanned hand image into a form. JPEG and then colored with Adobe Photoshop CS applications 6. The next was the process of designing Lay-out manuals using Microsoft Publisher 2016.

The next stage was the expert test. Based on the rubric that had been filled by the expert, it was found that the product developed in the form of manual of Character Based "Language Learning Games" had been in accordance with the syllabus used, the criteria of a good game, and the criteria of a good book. As a general comment, it was said that the activity of games was good as an alternative strategy for teaching as well as 
motivating students to learn. The games also gave students the opportunity to make decisions, make a strategy to win games, solve the obstacles encountered, and improve the spirit of play. The embedded character also complied with the applicable curriculum demands.

Regardless of the quality of the product that was good, there were some weaknesses that had to be perfected. The weaknesses included the book design, color, image placement, grammar errors, and some other similar errors. Based on these suggestions, revision was done.

Based on these procedures, it was found that games strategy helped students become active in the classroom. In addition, the product developed in this research meets several criteria, such as in accordance with the syllabus used, in accordance with the characteristics of a good game, and poured in a manual form that had been in accordance with the characteristics of a good manual. The manual had also been tested by an expert both in content and form of presentation and had been improved upon the advice of experts. The product of this research could be said to be very reliable in terms of content (the game that was designed) and reliable in terms of form (manual).

In the limited field test phase, teachers were given a questionnaire to fill in which was related to the teacher's assessment of the developed product. The questionnaire was the same as the sheet to be filled by the expert, so that the assessment was gotten according to the user (teacher). In addition, with the results of the questionnaire, the quality of the developed product could be known. In terms of game design and manuals, they were acceptable and did not get comments from teachers. Furthermore, the product value of teachers was summed and classified according to the formula of Nurkancana and Sunartana (the complete results could be seen in Product Quality Results). In the application, the teacher suggested thinking about classroom management so that students did not get too busy and did things that were not related to games or learning. But in a major outline, the products developed were in accordance with the syllabus, good games, as well as good guidebooks so they could motivate students to learn without pressure and implanted characters through games. The manual had also been well designed though it still required additional pictures in it.

Based on the results of students' questionnaires, it was also known that games as a strategy to teach English was very motivating students, giving students ease in reducing the pressure better than conventional teaching strategies.

Next, the results related to product quality obtained from the results of checks were filled by experts. The experts who assessed this product were 2 lecturers of English Education Department and a teacher of SMP Negeri 4 Singaraja. The results of expert judgments were then calculated and then converted using the following formula.

Table 1. Conversion Formulas

\begin{tabular}{cc}
\hline Value & Criteria \\
\hline $\mathrm{X} \geq \mathrm{Mi}+1,5 \mathrm{Sdi}$ & Excellent \\
$\mathrm{Mi}+0,5 \mathrm{Sdi} \leq \mathrm{X}<\mathrm{Mi}+1,5 \mathrm{Sdi}$ & Good \\
$\mathrm{Mi}-0,5 \mathrm{Sdi} \leq \mathrm{X}<\mathrm{Mi}+0,5 \mathrm{Sdi}$ & Average \\
$\mathrm{Mi}-1,5 \mathrm{Sdi} \leq \mathrm{X}<\mathrm{Mi}-0,5 \mathrm{Sdi}$ & Bellow Average \\
$\mathrm{X}<\mathrm{Mi}-1.5 \mathrm{Sdi}$ & Poor \\
\hline & (Nurkancana and Sunartana, 1992)
\end{tabular}

Note:

$\mathrm{Mi}=1 / 2($ Score Max + Score Min $)$

$\mathrm{Sdi}=1 / 3(\mathrm{Mi})$

$\mathrm{Mi}=$ Ideal Mean

Sdi $=$ Standard of Deviation

$\mathrm{X}=$ The score of the teacher.

Data analysis could be explained as follows:

- $\quad$ First, Mi and Sdi were obtained by the formula

$\mathrm{Mi}=1 / 2($ Score Max + Score Min $)$

$\mathrm{Sdi}=1 / 3(\mathrm{Mi})$

- $\quad$ Because the max value was 5 and the minimum value was 1 , then

$\mathrm{Mi}=1 / 2(95+19)$

$\mathrm{Mi}=1 / 2(114)$

$\mathrm{Mi}=57$

And Sdi:

Sdi $=1 / 3(57)$

$\mathrm{Sdi}=19$

- $\quad$ After finding that $\mathrm{Mi}=57$ and $\mathrm{Sdi}=19$, we could see the product quality criteria developed as follows: 
Table 2. Game Conversion Value

\begin{tabular}{cc}
\hline Value & Criteria \\
\hline $\mathrm{X} \geq 85,5$ & Excellent \\
$65,5 \leq \mathrm{X}<85,5$ & Good \\
$47,5 \leq \mathrm{X}<65,5$ & Avarage \\
$28,5 \leq \mathrm{X}<47,5$ & Bellow Avarage \\
$\mathrm{X}<28,5$ & Poor \\
\hline
\end{tabular}

(Nurkancana and Sunartana, 1992)

The values in the table above were then adjusted to the total value of each expert obtained based on the checklist. The results could be seen in the following table.

Table 3. Experts' Assessment Results on the Game

\begin{tabular}{ccc}
\hline Expert & Total Value & Rating \\
\hline Expert 1 & 86 & Excellent \\
Expert 2 & 85 & Good \\
\hline
\end{tabular}

Based on the results of the assessment of expert lecturers, developed games were categorized both for applied, clear, and in accordance with the level of students' ability. Games implementation meant it was flexible to use. These games could not only be used on a single topic however they could be applied to other topics that had the same character that had to be developed. Clarity meant having clear goals, rules, and procedures. The developed gap could also be easily applied by teachers. The level of difficulty in games developed was also in accordance with the ability of students based on the existing objectives in the syllabus.

The experts' results showed that the games developed were in accordance with standard competency, basic competency, and indicators on the syllabus used. Regarding the good game criteria by Prensky, Uberman, and Kaluer, there were two aspects that were filled by experts, namely aspects of motivation and content aspects. From the results of the checklist, it appeared that the aspect of motivation looked very appropriate because of the challenge on games was in accordance with the level of student ability and gave them the opportunity to make decisions during the play. While on the content aspect, it referred more to the suitability of games developed with the purpose of learning and how games were presented in each format in the manual. The experts' assessment results showed that each item was appropriate. However, although experts' judgments were appropriate, there were some comments from experts such as grammatical errors as well as applying games that should be made according to student levels so that students were more challenged to finish games and explore more with their knowledge of the topic.

Furthermore, the quality of the developed books could also be analyzed by the same formula. The calculation could be seen as follows.

$$
\begin{aligned}
& \mathrm{Mi}=1 / 2(55+11) \\
& \mathrm{Mi}=1 / 2(66) \\
& \mathrm{Mi}=33
\end{aligned}
$$

And

$$
\begin{aligned}
& \text { Sdi }=1 / 3(33) \\
& \text { Sdi }=11
\end{aligned}
$$

Table 4. Manual Conversion Value

\begin{tabular}{cc}
\hline Value & Criteria \\
\hline $\mathrm{X} \geq 49,5$ & Excellent \\
$27,5 \leq \mathrm{X}<49,5$ & Good \\
$33 \leq \mathrm{X}<27,5$ & Average \\
$16,5 \leq \mathrm{X}<33$ & Bellow Avarage \\
$\mathrm{X}<16,5$ & Poor \\
\hline
\end{tabular}

The values in the table above were then adjusted to the total value of each expert obtained based on the checklist. The results could be seen in the following table. 
Table 5. Experts' Assessment Results towards Manual

\begin{tabular}{ccc}
\hline Expert & Total Value & Rating \\
\hline Expert 1 & 51 & Excellent \\
Expert 2 & 52 & Excellent \\
\hline
\end{tabular}

Related to the making of the manual, the experts were also given rubric criteria of good books from Puskurbuk. The experts were asked to fill out the rubric about the 4 components of the book, namely aspects of language, display aspects, aspects of readability, and graphics aspects. The results showed that the language aspect was considered quite appropriate because there were some grammatical errors. While in other aspects, it was considered very appropriate. It was added by the experts that the placement of lines, drawings, and other attributes had to be observed so that in the stage of the page, there was not too much void space.

The quality of the product was also assessed by the user, the teacher at the school. The teacher got the same checklist to assess the quality of games being developed and the manual. The advice given by teachers in the form of class management should be added so that when implementing media in the classroom, there was no unexpected disturbance. Apart from that, the implementation of games developed was said to have changed the learning situation where students were very eager to learn by playing without feeling depressed and anxious. The games application in developing characters was also evident when students had to follow the rules of games with discipline, confidence in answering, and tolerance in waiting their turn.

Based on teacher grades, the quality of the games developed was as follows:

Table 6. Results of the Teacher's Assessment of the Game

\begin{tabular}{ccc}
\hline Expert & Total Value & Rating \\
\hline Teacher & 72 & Good \\
\hline
\end{tabular}

The total score given by the teacher was 72 . The value corresponded to the conversion which was also used in the value of the two experts, of which 72 could be interpreted that the games developed were a good game. teacher.

In relation to the quality of the developed manuals, the following table showed the details given by the

Table 7. Results of Teacher Assessment towards Manual

\begin{tabular}{c|c|c}
\hline Expert & Total Value & Rating \\
\hline Teacher & 49 & Good \\
\hline
\end{tabular}

Based on the above table, the developed manuals got a value of 49 which meant that the manuals developed were of good quality.

Based on the calculation of the value of both experts and teachers, it could be concluded that the products developed were of good quality.

\section{Discussion}

In the process of needs analysis, it was found that the seventh graders still had low interest in English. This was evident from the results of in-depth observations made with teachers and the results of questionnaires filled by students. The low interest of students was mainly due to the teacher's teaching strategy that explained more followed by answering questions. As a result, students became bored quickly and unmotivated. Cameron (2001) mentioned that young learners (in this study the seventh-grade of junior high school students) were more passionate learners than adult learners. Martin (2003) delivered that students who were enthusiastic about learning were students who had motivation in the learning. However, learners at that age were very easy to lose their motivation and interest in learning (Cameron, 2001). For that, it was necessary for teachers to carefully choose a more innovative and fun strategy in teaching so that students' motivation could be improved. Based on these conditions, games became a good alternative solution to increase students' interest in learning, especially English. Tuan \& Nguyen (2010) explained that games really helped reduce students' learning difficulties and created a learning atmosphere to be more fun. Especially for students at that level, games gave a good effect to improve their achievement because students at that age were still in the early stages of learning English and games were able to create an interactive learning environment (Mubaslat, 2011).

In developing this research product, there were 3 types of games developed. The game play was developed based on syllabus, good game criteria, and character to be developed. The games were Word Brick, 
Monopoly, and Snake and Ladder. These types of game were chosen because they were very easy to find in the daily life of students that made students feel that they could participate in real situations and as a result, they acted naturally, like in real life (Ubberman, 1998). The developed game play was also able to bring character education to the students because in the games, students were accustomed to patience and tolerance to wait their turn to play, helped each other when finding obstacles, and competed fairly and friendlily. This was in line with the opinion of Tyson (2000) that a good game should contain a friendly feeling of competition.

After games and manuals were developed, the evaluation was done by the experts on both aspects of games, as well as the manual. The experts' assessment results showed that games and manuals developed were good games and good manuals. Afterward, when field trials were limited, it was known that students were very enthusiastic and motivated in learning English by playing. The good character of the students also began to appear even though this did not apply to every student. The teacher also agreed that games motivated students in learning but by preparing carefully how to control the classroom as games progressed. In addition, from the results of students' questionnaires, it was known that they were very happy and feel motivated to learn with games. Students' participation also increased with the challenge of finding new words through games. This was not much different from what Azar described (2012) i.e. learning a new language and vocabulary through games was a significant and interesting way that could be applied to students with a relatively low ability. For that, games developed in this study were very helpful to students to improve motivation that led to improving their English skills.

The final product in this study was entitled 'Character Based Language Learning Games for 1st Grade Junior High School'. This manual consisted of 49 pages consisting of 3 chapters, 3 materials, and 3 different game types. The game was Word Brick Game (to teach adjectives of people/ animals/ things), Race Words Game (to teach duty/ behavior / function of people/ animals / things) and Snake and Signs Game (to teach the meaning of signs/ warning ). The material had been adapted to the syllabus used in the school.

\section{Conclusion}

Based on data analysis and discussion in the previous chapter, some conclusions could be drawn, ie there were 3 types of games developed in this research, namely Word Brick Game, Word Race Game and Snake and Signs game. Each game was inserted each character that would be implanted in the students through games. In addition, the next conclusion was a product developed in good quality, as a result of expert assessment as well as teachers in the school. According to students, the product was also categorized as a fun and motivating game. Based on the results of this study, it was advisable for English teachers to use the products in this study so that classroom learning becomes more innovative and fun. In addition, teachers could also apply it as a strategy in classroom action research to improve students' skills in English subjects. Related to the limitations of this study, which the product produced was still a prototype, it was also suggested to other researchers to conduct a wider test in other schools to see the effectiveness of products developed.

\section{References}

Aslanabadi, H., Rasouli, G. (2013). The Effect of Games on Improvement of Iranian EFL Vocabulary Knowledge in Kindergartens. International Review of Social Sciences and Humanities, Vol. 6, No. 1 (2013), Hal. 186-195

Azar, A.S. (2012). The Effect of Games on EFL Learners' Vocabulary Learning Strategies. International Journal of Basic and Applied Science, Vol 01, No. 02, Oct 2012, hal. 252-256

Bradley, L., Lindstrm, B \& Rystedt, H. (2010). Rationalities of Collaboration for Language Learning in a Wiki, ReCALL, 22(2) (2010), 247-265.

Cameron, L. (2001) Teaching languages to young learners. Cambridge: Cambridge University Press

Diana, Nova Pravita Rus (2010). The advantages and disadvantages of using games in teaching vocabulary to the third graders of top school elementary school. Retrieved from http://eprints.uns.ac.id/336/1/166750209201011411.pdf.

Ersoz, A. (2000). 'Six Games for the EFL/ESL Classroom', in The Internet TESL Journal. Retrieved July 13, 2012 from http://iteslj.org/Lessons/Ersoz-Games.html .

Kemdiknas. (2010). Rencana Aksi Nasional Pendidikan Karakter. Jakarta.

Koksal, U., Cekic, A., \& Beyhan, O. (2014). Views od Turkish EFL Students with Regard to Learning Grammar with Games. International Journal on New Trends in Education and Their Implications. Vol:5, Issue:1, Article:,09, Jan 2014, hal. 82-92.

Martin. A. (2003). Motivating students to learn. Retrieved from: https://www.psychology.org.au/publications/inpsych/motivating/. Accessed April 2016 
Masri, A.A., Najar, M.A. (2014). The Effect of Using Word Games on Primary Stage Students Achievement in English Language Vocabulary in Jordan. American International Journal of Contemporary Research, Vol. 4, No. 9; September 2014, Hal. 114-152.

Mulyasa. E. (2013). Pengembangan dan Implementasi Kurikulum 2013. Bandung: PT. Remaja Rosdakarya.

Mubaslat, M. M. (2011). The Effect of Using Educational Games on the Students' Achievement in English Language for the Primary Stage.

Richard, G. \&Rogers, J. (2001). The Practice of English Language Teaching. Oxford: Longman.

Sugiyono. (2011). Metode Penelitian Kuantitatif, Kualitatif, dan R\&D. Bandung: Penerbit Alfabeta.

Tuan.L.T \&.Nguyen.(2010) Teaching English grammar through games. Studies in Literature and Language Vol. 1 , No. 7, pp. 61-75

Uberman, A. (1998). 'The use of games for vocabulary presentation and revision'. Forum, 36(1), $20-27$. Retrieved February 12, 2006, from http://exchanges.state.gov/forum/vols/vol36/no1/p20.htm .

Wright, A., Batteridge, D., \& Buckby, M. (2005). Games for Language Learning(3rd ed.). New York: Cambridge University Press. 